\title{
A UNIFORMIDADE INTERPRETATIVA DO DIREITO: UMA ANÁLISE
} RETROSPECTIVA ${ }^{1-2}$

\section{THE INTERPRETATIVE UNIFORMITY OF LAW: A RETROSPECTIVE ANALYSIS}

\section{Cintia Garabini Lages}

Doutora e Mestre em Direito Processual pela PUC MINAS, bacharela em Direito pela Faculdade de Direito da Universidade Federal de Minas Gerais (1998). Atualmente é professora do Programa de Pós-Graduação stricto sensu Mestrado em Proteção dos Direitos Fundamentais - e da graduação, curso de Direito, da Universidade de Itaúna. Professora Adjunta da Faculdade Mineira de Direito da Pontifícia Universidade Católica de Minas Gerais, unidades Coração Eucarístico e Betim, coordenadora de Pesquisa da PUC Minas Betim, coordenadora de Pesquisa da Faculdade Mineira de Direito da PUC Minas Betim, e Editora Chefe da Revista Sinapse Múltipla. Líder dos grupos de pesquisa "Constituição, Processo e Democracia" e "Observatório Constitucional". Belo Horizonte/MG. E-mail: cintiagarabini@gmail.com

RESUMO: O presente artigo busca reconstruir procedimentos judiciais de uniformização da interpretação do Direito empregados no âmbito do Direito Processual Civil brasileiro. O objetivo da análise é o de evidenciar que a instituição de procedimentos voltados à formulação de uma interpretação coerente do Direito pelos órgãos judiciários apresenta-se como a forma jurídica moderna de garantia da segurança jurídica e coerência decisória no âmbito jurisdicional. Metodologicamente, adotou-se o procedimento da revisão bibliográfica, sendo a pesquisa descritiva. A análise dos procedimentos permite concluir que

\footnotetext{
${ }^{1}$ Artigo recebido em 28/12/2020 e aprovado em 20/04/2021.

${ }^{2}$ Artigo vinculado ao Grupo de Pesquisa Constituição, Processo e Democracia.
} 
a busca por uma interpretação coerente do Direito se perfaz como uma constante na história do Direito Processual brasileiro.

PALAVRAS-CHAVE: Uniformidade. Direito Processual Civil. Procedimentos. Interpretação. Historicidade.

ABSTRACT: This article seeks to reconstruct judicial procedures for the standardization of the interpretation of Law employed by Brazilian Civil Procedural Law. The objective of the analysis is to show that the institution of procedures aimed at the formulation of a coherent interpretation of the Law by the judicial bodies presents itself as the modern legal form of guarantee of legal certainty and coherence decision within the jurisdiction. Methodologically, the literature review procedure was adopted, with descriptive research. The analysis of the procedures allows us to conclude that the search for a coherent interpretation of Law is a constant in the history of Brazilian Procedural Law.

KEYWORDS: Uniformity. Civil Procedure Law. Procedure. Interpretation. Historicity.

\section{Introdução}

A preocupação com a interpretação segura e coerente do Direito por parte dos órgãos judiciários no exercício da jurisdição não é recente, nem mesmo pode ser imputada a um determinado sistema jurídico. Coerência e segurança jurídica são exigências inerentes ao Direito moderno, fundado no reconhecimento de direitos fundamentais e no regime democrático, a demandarem do Poder Judiciário uma atuação capaz de assegurar que o provimento jurisdicional possa ser visto como uma obra única e coerente, ainda quando interpretado e aplicado por uma pluralidade de órgãos judiciários3.

A interpretação do Direito voltada para a sua aplicação por parte dos juízes e tribunais levanta questionamentos variados, concernentes tanto em relação aos seus limites à luz do

\footnotetext{
${ }^{3}$ LAGES, Cintia Garabini; CHAMON JUNIOR, Lúcio Antônio. Acerca da segurança jurídica e da uniformidade das decisões a partir do novo código de processo civil à luz do modelo constitucional do processo brasileiro. Rev. Bras. Polít. Públicas, Brasília, v. 7, nº 2, p. 285-301, ago. 2017. p. 285.
} 
princípio da separação de poderes, quanto em relação à sua coerência, em face da pluralidade orgânica própria do Poder Judiciário.

Ao contrário dos Poderes Legislativo e Executivo, que possuem estrutura simplificada em termos orgânicos, o Poder Judiciário apresenta uma composição plural, organizada internamente segundo a lógica de repartição de competências. Juízes e tribunais compartilham uma mesma função e a exercem simultaneamente, interpretando e aplicando o Direito para a solução das controvérsias submetidas por meio do exercício do direito de ação. A adoção de uma interpretação do Direito pela pluralidade de órgãos integrantes da estrutura judiciaria representa, historicamente, um desafio.

Nesse contexto, a função exercida pelo Direito Processual é fundamental, a possibilitar a adoção de procedimentos capazes de garantir ao jurisdicionado decisões judiciais coerentes tanto em relação ao caso concreto, quanto em relação a uma compreensão compartilhada do ordenamento jurídico, ainda que produto de uma pluralidade de órgãos judiciários.

A discussão relativa à relevância da interpretação do Direito no contexto da jurisdição e sua uniformidade, foi retomada pelo novo Código de Processo Civil (2015), e realiza-se na função desempenhada pelos precedentes judiciais, parâmetros decisórios de observância obrigatória, e na instituição de novos procedimentos definidores de precedentes. Em função da atualidade desta discussão, o presente trabalho pretende reconstruir procedimentos judiciais que, ao longo da história jurídico-institucional brasileira, do Império até a edição do Código de Processo Civil de 1973, foram adotados com a finalidade de promover certeza e segurança na aplicação do Direito por parte dos órgãos judiciários. Seu objetivo é o de evidenciar que os procedimentos adotados pela Lei 13.105/2015, atual Código de Processo Civil, não se caracterizam pelo ineditismo, ao contrário, perfazem-se como o desenvolvimento do Direito Processual Brasileiro na busca por uma prática jurisdicional mais segura e democrática.

Para tanto, não se pretende esgotar o catálogo de procedimentos de uniformização da interpretação do direito pelos tribunais, mas apenas reconstruir, em linhas gerais, uma história iniciada muito antes do atual Código de Processo Civil, mas que este a evidenciou. Desta forma, configuram objeto de análise no presente artigo os procedimentos judiciais empregados o âmbito do Direito Processual Civil brasileiro compreendidos entre o período imperial e a edição do Código de Processo Civil de 1973 (excluída do presente trabalho a 
análise deste), dentre os quais destacam-se os assentos da Casa da Suplicação, os procedimentos estaduais de uniformização da jurisprudência adotados durante a vigência da Constituição brasileira de 1891, o recurso de revista, o prejulgado e as súmulas do Supremo Tribunal Federal.

O recorte temporal justifica-se dada a extensão da análise dos procedimentos identificados, e os estreitos limites impostos pela forma de comunicação escolhida para o presente trabalho. Metodologicamente, a pesquisa caracteriza-se como sendo do tipo descritiva, e para sua realização foi adotado o procedimento da revisão bibliográfica. A conclusão do artigo é resultado de uma análise dedutiva.

\section{Acerca da uniformidade decisória no Império: os assentos da Casa da Suplicação e do Supremo Tribunal de Justiça}

Após a independência do Brasil Colônia do estado português e sua constituição em um estado soberano, a existência de um ordenamento jurídico brasileiro foi garantida com a edição da Lei de 20 de novembro de 1.823 , segundo a qual toda a legislação portuguesa editada até a data do retorno da família real à Portugal, bem como a editada por D. Pedro na qualidade de representante do trono português, foi recepcionada e permaneceu em vigor até a sua posterior substituição por novas leis brasileiras. Incluíam-se na legislação portuguesa recepcionada as ordenações, os regimentos, alvarás, decretos e resoluções.

No que tange à matéria processual, a principal legislação herdada pelo Brasil do estado português, foram as Ordenações Filipinas, também denominadas Ordenações do Reino, resultantes do processo de reforma legislativa empreendida por Felipe II da Espanha - Felipe I de Portugal, ao Código Manuelino, durante o período em que vigorou a União Ibérica.

No Brasil, mesmo com a declaração da independência, ainda continuaram a vigorar as leis portuguesas atinentes ao processo. Valiam, então, naquilo em que não fosse contrariada a soberania nacional, as normas processuais civis contidas nas Ordenações Filipinas (Livro III), cujo processo ali disciplinado caracterizava-se como sendo escrito, com fases rígidas, marcado pelos princípios da iniciativa da parte e do dispositivo.4

${ }^{4}$ VIANA, Juvêncio Vasconcelos. História do processo: uma análise do Código de Processo Civil de 1939 sob o prisma terminológico. Revista da Procuradoria Geral do Município de Fortaleza, Fortaleza, v. 9, p. 129-162, 
As Ordenações Filipinas eram compostas por cinco livros: o primeiro estabelecia normas relativas à organização judiciária do Reino; o segundo estabelecia normas especiais, isenções e privilégios, aplicáveis ao clero; o terceiro livro instituía o Direito Processual Civil; o quarto regulava o Direito Civil, contratos, direitos reais e direito de família; e o quinto livro estruturava o Direito Penal e Processual penal do Reino.5

A preocupação com a interpretação uniforme das leis do Reino e sua aplicação às situações concretas encontra previsão expressa no Livro I, Título V, item 5o, que regulava a competência da Casa da Suplicação para a edição de assentos:

E havemos por bem, que quando os Desembargadores, que forem no despacho de algum feito, todos ou algum delles tiverem alguma dúvida em alguma nossa Ordenação do entendimento della, vão com a dúvida ao Regedor; o qual na Mesa grande com os Desembargadores, que lhe bem parecer, a determinará, e segundo o que ahi for determinado, se porá a sentença. E a determinação que sobre o entendimento da dita Ordenação se tomar, mandará o Regedor screver no livro da Relação, para depois não vir em dúvida. (...) $\mathrm{E}$ os que em outra maneira interpretarem nossas Ordenações ou derem sentenças em algum feito, tendo algum deles dúvida no entendimento da Ordenação, sem ir ao Regedor, será suspenso até nossa mercê. ${ }^{6}$

As Ordenações Filipinas estruturaram, a exemplo do estabelecido pelas Ordenações Manuelinas, um procedimento de uniformização da interpretação da lei que resultava na edição de um provimento, denominado assento, levado a registro no livro da Relação. Os assentos proferidos pela Casa da Suplicação, órgão de cúpula do Poder Judiciário português, possuíam força vinculante, como ressalta Cruz e Tucci, citando Braga da Cruz:

\footnotetext{
Os julgamentos que então eram efetivados à luz dessas leis e devidamente registrados no "livrinho" logo "tomaram o nome de 'assentos'; e tinham um valor normativo em tudo idêntico ao das próprias leis interpretadas", e, portanto, "projetavam eficácia vinculativa para casos futuros semelhantes".
}

A interpretação contida nos assentos possuía caráter abstrato, referindo-se à norma objeto de aplicação, sem conexão com a situação fática concreta objeto de análise pelo órgão

2001. Disponível em: https://revista.pgm.fortaleza.ce.gov.br/revista1/issue/view/9/ano2001. Acesso em: 02 nov. 2016.

${ }^{5}$ RIBEIRO, Teóphilo. As Ordenações do Reino. Revista da Faculdade de Direito da UFMG, Belo Horizonte, v. $5, \quad$ p. $155-208, \quad$ abr. $2014 . \quad$ Disponível em: <https://www.direito.ufmg.br/revista/index.php/revista/article/view/1367/1299>. Acesso em: 10 dez. 2017.

${ }^{6}$ RIBEIRO, Teóphilo. As Ordenações do Reino. Revista da Faculdade de Direito da UFMG, Belo Horizonte, v. 5, p. $155-208, \quad$ abr. $2014 . \quad$ Disponível https://www.direito.ufmg.br/revista/index.php/revista/article/view/1367/1299. Acesso em: 10 dez. 2017.

${ }^{7}$ CRUZ E TUCCI, José Rogério. Tradição luso-brasileira dos assentos da Casa da Suplicação. São Paulo: Atlas, 2012. 
judiciário8, e constituía uma forma de interpretação autêntica do Direito, reforçando a autoridade do soberano em estabelecer o Direito. ${ }^{9}$

No mesmo sentido, João Mendes de Almeida Júnior afirmou tratarem-se os assentos da Casa da Suplicação atos do Poder Judiciário cujo conteúdo possui determinações sobre a interpretação das leis, adotados quando o sentido do ato legislativo constituísse objeto de dúvida e diferenciavam-se dos assentos dos arestos em razão da natureza concreta destes, em oposição ao caráter geral dos assentos ${ }^{10}$.

Infere-se dos estudos de Mendes Júnior e Carmignani que os assentos da Casa da Suplicação configuravam instrumento de uniformização da interpretação da legislação de caráter geral e vinculante com relação aos demais órgãos judiciários. Os assentos não eram editados em face de uma situação concreta de aplicação, mas tinham por objeto a lei em abstrato, produzindo, desta forma, uma eficácia geral.

O caráter vinculante, abstrato e definitivo da interpretação afirmada nos assentos editados pela Casa da Suplicação foi reforçado pela Lei 18 de agosto de 1.769, denominada Lei da Boa Razão, adotada com a finalidade de assegurar uniformidade na interpretação do Direito e pôr fim aos abusos cometidos pelos tribunais inferiores ${ }^{11}$. Previa o $\S 2^{\circ}$. da referida lei que os assentos estabeleciam a inteligência geral e perpétua da lei, possuíam caráter vinculante e o único recurso admitido contra os mesmos era o recurso ao monarca ${ }^{12}$.

[...] verificando-se que algum ou alguns dos Desembargadores, ou julgaram contra a expressa determinação da Lei; ou que em logar de julgarem o direito das partes, julgaram a intelligencia duvidosa da Lei pelo seu próprio arbítrio, antes de recorrerem ao Regedor para elle na Mesa grande fazer tomar Assento sobre a interpretação do genuíno sentido da mesma Lei: Mando, que o Chanceller supprindo neste caso o que os sobredictos Desembargadores deveriam ter feito; leve immediatamente os Autos ao Regedor com a glosa, que nelles houver posto, para sobre ella se tomar Assento decisivo na fôrma abaixo declarada. E ordeno que a esta

\footnotetext{
${ }^{8}$ CARMIGNANI, Maria Cristina da Silva. O direito judiciário lusitano - os assentos da casa da suplicação. Revista da Faculdade de Direito, Universidade de São Paulo, São Paulo, v. 111, p. 19-29, jun. 2017. Disponível em: <https://www.revistas.usp.br/rfdusp/article/view/133541/129548>. Acesso em: 16 jan. 2018. ${ }^{9}$ CRUZ E TUCCI, José Rogério. Tradição luso-brasileira dos assentos da Casa da Suplicação. São Paulo: Atlas, 2012.

${ }^{10}$ ALMEIDA JUNIOR, João Mendes de. Direito Judiciário brasileiro. 5. ed. Rio de Janeiro: Freitas Bastos, 1960.

11 CARMIGNANI, Maria Cristina da Silva. O direito judiciário lusitano - os assentos da casa da suplicação. Revista da Faculdade de Direito, Universidade de São Paulo, São Paulo, v. 111, p. 19-29, jun. 2017. Disponível em: https://www.revistas.usp.br/rfdusp/article/view/133541/129548. Acesso em: 16 jan. 2018.

12 TELLES, José Homem Correa. Commentário crítico à Lei da Boa Razão em data de 18 de agosto de 1769. Lisboa: Typographia de Maria Madre de Deus, 1.865.
} 
glosa, e Assento sobre ella tomado neste caso, em que se não julga o direito das partes no particular de cada uma d'ellas, mas sim a intelligencia geral, e perpetua da Lei em commum beneficio, não possa haver embargos, nem outro algum recurso, que não seja aquelle imediato à a Minha Real Pessoa, de que nunca é visto serem privados os Vassallos ${ }^{13}$.

Nesse sentido, as Ordenações Filipinas previam um instrumento de uniformização da interpretação da lei aplicável pelos demais órgãos judiciários e que foi incorporado ao ordenamento jurídico brasileiro quando da recepção da legislação portuguesa após a independência do Brasil.

Com a nova Constituição, adotou-se um novo arranjo na organização judiciária: no lugar da Casa da Suplicação, tem-se como órgão de cúpula o Supremo Tribunal de Justiça, com sede na Capital do Império. Os demais órgãos judiciários restringiam-se aos juízes, que aplicavam a lei, aos jurados, que conheciam dos fatos, ambos órgãos de primeira instância, e às Relações, tribunais de segunda e última instância, uma para cada província, nos termos do artigo 158 da Constituição Imperial ${ }^{14}$.

O Supremo Tribunal de Justiça não foi considerado uma terceira instância, sobretudo em função deste tribunal não possuir competência para proceder à revisão dos julgados proferidos pelas Relações ${ }^{15}$. Não se conhece um procedimento de padronização da interpretação do Direito distinto dos assentos da Casa da Suplicação recepcionados em 1823.

Somente com a edição do Decreto Legislativo 2.684, de 30 de novembro de 1875, um novo instrumento foi introduzido com a finalidade de garantir, no âmbito da organização jurídica do Império, um mínimo de uniformidade na interpretação e aplicação da lei por parte dos tribunais. Tal decreto atribuiu aos assentos da Casa da Suplicação caráter vinculante e inovou ao regulamentar a possibilidade de edição de assentos também por parte do Supremo Tribunal de Justiça relativos à interpretação das leis civis, comerciais e criminais, na hipótese de dúvidas manifestadas pelos tribunais - Relações - e juízes de primeira instância. Nesse sentido, dispunha o artigo 2o. do referido decreto:

\footnotetext{
13 TELLES, José Homem Correa. Commentário crítico à Lei da Boa Razão em data de 18 de agosto de 1769. Lisboa: Typographia de Maria Madre de Deus, 1.865.

${ }^{14}$ Art. 158. Para julgar as causas em segunda e última instância haverá nas Províncias do Império as Relações, que forem necessárias para comodidade dos povos.

${ }^{15}$ NOGUEIRA, Octaciano. Constituições Brasileiras: 1824. Brasília: Senado Federal e Ministério da Ciência e Tecnologia, Centro de Estudos Estratégicos, 2001.
} 


\begin{abstract}
Art. $2^{\circ}$ Ao Supremo Tribunal de Justiça compete tomar assentos para intelligencia das leis civis, commerciaes e criminaes, quando na execução dellas occorrerem duvidas manifestadas por julgamentos divergentes havidos no mesmo Tribunal, Relações e Juizos de primeira instancia nas causas que cabem na sua alçada.

$\S 1^{\circ}$ Estes assentos serão tomados, sendo consultadas previamente as Relações.

$\S 2^{\circ}$ Os assentos serão registrados em livro proprio, remettidos ao Governo Imperial e a cada uma das Camaras Legislativas, numerados e incorporados á collecção das leis de cada anno; e serão obrigatorios provisoriamente até que sejam derogados pelo Poder Legislativo. ${ }^{16}$
\end{abstract}

Verifica-se, entretanto, um lapso temporal significativo entre a data da publicação da Constituição Imperial, e a da edição do Decreto Legislativo em apreço, lapso dentro do qual o Supremo Tribunal de Justiça não tinha competência para a edição de assentos, nem mesmo possuía competência recursal constitucionalmente prevista para estabelecer uma interpretação capaz de servir de paradigma aos tribunais provincianos. Durante todo esse período, coube, segundo Nogueira, ao Executivo, e em especial ao Conselho de Estado, a função de uniformização da interpretação da lei ${ }^{17}$, não obstante a função interpretativa das leis ter sido atribuída, pela Constituição, ao legislador. ${ }^{18} \mathrm{O}$ encaminhamento das dúvidas sobre a interpretação das leis ao Conselho de Estado por parte dos membros do Poder Judiciário, tornou-se comum, o que importou em uma prática protelatória disseminada no Império ${ }^{19}$.

\title{
3. A uniformização da interpretação do Direito no âmbito da competência legislativa estadual
}

Com a proclamação da República, uma nova organização política foi adotada, culminando com a forma federativa de estado, cuja nota característica reside na descentralização política e consequente coexistência de entes políticos autônomos. Assim, a

\footnotetext{
${ }^{16}$ BRASIL. Decreto n. 2.684, de 23 de outubro de 1875. Dá força de lei no Imperio a assentos da Casa da Supplicação de Lisboa e competencia ao Supremo Tribunal de Justiça para tomar outros. Disponível em: https://www2.camara.leg.br/legin/fed/decret/1824-1899/decreto-2684-23-outubro-1875-549772publicacaooriginal-65290-pl.html. Acesso em: 25 jan. 2018.

${ }^{17}$ NOGUEIRA, Octaciano. Constituições Brasileiras: 1824. Brasília: Senado Federal e Ministério da Ciência e Tecnologia, Centro de Estudos Estratégicos, 2001.

${ }^{18}$ Nos termos do artigo 15, inciso VIII da Constituição Imperial.

${ }^{19}$ NOGUEIRA, Octaciano. Constituições Brasileiras: 1824. Brasília: Senado Federal e Ministério da Ciência e Tecnologia, Centro de Estudos Estratégicos, 2001.
} 
Rio de Janeiro. Ano 15. Volume 22. Número 3. Setembro a Dezembro de 2021

Periódico Quadrimestral da Pós-Graduação Stricto Sensu em Direito Processual da UERJ

Patrono: José Carlos Barbosa Moreira (in mem.). ISSN 1982-7636. pp. 192-219 www.redp.uerj.br

Constituição da República dos Estados Unidos do Brasil, promulgada em 24 de fevereiro de 1891, transformou as antigas províncias do Império, meras descentralizações administrativas, em entes políticos, pessoas jurídicas de direito público interno dotados de autonomia, atribuindo-lhes competências legislativas, administrativas, tributárias e jurisdicionais próprias.

O Poder Judiciário nacional foi reestruturado, contemplando uma justiça federal e outra estadual, unificadas por um órgão de cúpula, o Supremo Tribunal Federal. Ressalte-se que tanto o Supremo Tribunal Federal quanto a Justiça Federal foram criados e organizados antes mesmo da promulgação da Constituição de 1891, através de decretos editados pelo Governo provisório $^{20}$. Tal organização foi mantida, em suas linhas gerais, quando da promulgação da Constituição definitiva.

A Constituição Federal de 1891, entretanto, não organizou de modo pormenorizado quer a Justiça Federal, quer a Estadual, fazendo referência genérica aos tribunais e juízes federais e estaduais, sem individualizá-los.21 A definição da estrutura judiciária estadual foi reservada às Constituições estaduais, como expressão do exercício da autonomia política conferida aos Estados, e a organização judiciária federal foi definida pela legislação federal. $^{22}$

A criação de duas estruturas judiciárias distintas trouxe desafios no que diz respeito aos procedimentos de uniformização do Direito, sobretudo em função da rem partição da competência legislativa em matéria processual adotada pela Constituição de 1891, pois a competência para legislar sobre matéria processual foi atribuída tanto aos Estados quanto à União, sendo que a esta competia editar leis sobre o processo no âmbito da justiça federal e àqueles competia legislar sobre o processo no âmbito da justiça estadual.

Não apenas a Constituição de 1891 estruturou um judiciário dúplice, federal e estadual, mas definiu que cada um deles atuaria segundo um sistema processual próprio. A dificuldade maior, segundo Virgílio Martins de Mello Franco, era a de assegurar uma interpretação

\footnotetext{
${ }^{20}$ Neste sentido, o Decreto 510, de 22 de junho de 1890, que estabeleceu uma Constituição provisória para o Estado brasileiro, definindo a composição e competências do STF, bem como instituiu a Justiça Federal.

${ }^{21}$ De modo diverso, a atual Constituição relaciona em rol taxativo todos os órgãos que integram o Poder Judiciário nacional. Nesse sentido, o artigo 92 da Constituição da República Federativa do Brasil de 1988.

${ }^{22}$ A organização da Justiça Federal foi estabelecida pelo Governo Provisório, antes da promulgação da nova Constituição, pelo Decreto 848, 11 de outubro de 1890, considerado o marco inicial da organização judiciaria federal. Posteriormente foi editada a Lei 221, de 20 de novembro de 1894, que complementando o Decreto 848 , definiu a organização e o processo no âmbito da justiça federal.
} 
uniforme da legislação federal, aplicável tanto por órgãos judiciários federais, quanto estaduais, sem a previsão de procedimentos de uniformização da interpretação do Direito. ${ }^{23}$

Naquele momento, o Supremo Tribunal Federal não possuía competência para conhecer, processar e julgar recurso fundado na divergência de interpretação da legislação ordinária entre órgãos judiciários, mas tão somente competência para conhecer de recurso baseado na divergência acerca da interpretação de normas constitucionais, ou seja, recursos relativos à validade ou aplicação de leis federais e estaduais (artigo 59, 3. §1o).

O único dispositivo relativo à interpretação jurídica harmônica a ser realizada por órgãos judiciários estaduais e federais, o item 3. §2o do artigo 59 da Constituição de 1891, não estabelecia procedimento ou definia competência, mas tão somente estatuía que os órgãos judiciários estaduais, ao aplicarem a legislação federal, deveriam consultar a jurisprudência dos Tribunais Federais, assim como os órgãos da Justiça Federal deveriam consultar a jurisprudência dos tribunais locais ao aplicarem a lei estadual. Tal dispositivo não estruturou, entretanto, procedimento capaz de assegurar a obrigatoriedade da consulta e o respeito à interpretação adotada pelos órgãos judiciários competentes. ${ }^{24}$

A Constituição do Estado de Minas (1891), por sua vez, estabeleceu a possiblidade de criação de um tribunal especial com competência para dirimir conflitos interpretativos e a revisão de julgados identificados no âmbito do Poder Judiciário estadual.

Art. 73 - Poderá ser instituído, quando convier à administração da justiça, o júri civil, e criado um tribunal de revisão incumbido de uniformizar a jurisprudência e rever os julgamentos, nos casos de expressa violação da lei. O número de seus membros não excederá de cinco. $^{25}$

Referido tribunal não chegou a ser instituído. Em âmbito nacional, também era inexistente um sistema de uniformização capaz de alinhar a interpretação do Direito realizada por distintos órgãos federais e estaduais componentes da estrutura judiciária

\footnotetext{
${ }^{23}$ FRANCO, Virgílio Martins de Mello. A jurisprudência na organização do Direito Civil pátrio. Revista da Faculdade Livre de Direito do Estado de Minas Gerais, Ouro Preto, ano 1, n. 1, p. 93-100, 1894. Disponível em: https://www.direito.ufmg.br/revista/index.php/revista/article/view/438/407. Acesso em: 20 dez. 2017.

${ }^{24}$ BRASIL. [Constituição (1891)]. Constituição dos Estados Unidos do Brasil, de 24 de fevereiro de 1891. Disponível em http://www.planalto.gov.br/ccivil_03/Constituicao/Constituicao91.htm. Acesso em: 01 ago. 2016.

${ }^{25}$ MINAS GERAIS. Constituição Política do Estado de Minas Gerais, de 15 de junho de 1891. Disponível em:

https://www.almg.gov.br/consulte/legislacao/completa/completa.html?tipo=CON\&num=1891\&comp=\&ano $=1891$. Acesso em: $30 \mathrm{dez} .2017$.
} 
nacional. Nesse sentido, denunciou Virgílio Martins de Mello Franco ao analisar a evolução da jurisprudência na organização do Direito brasileiro:

Hoje temos, é certo, o Supremo Tribunal Federal, com a sua competencia restricta nos termos do artigo 59, no. 3 , § 1o. a) e b) da Constituição; mas essa competencia incompleta e restricta não basta para a informidade da jurisprudência, elemento organisador do direito civil e pátrio. ${ }^{26}$

No exercício da sua competência legislativa processual, o Estado de Minas Gerais editou duas leis durante a vigência da Constituição de 1891, a de $\mathrm{n}^{\circ} .17$, de 20 de novembro de 1891, revogada posteriormente pela Lei 830, de 07 de setembro de 1922, que estabeleceu o Código de Processo Civil do Estado mineiro.

A Lei 17/1891 estabeleceu um procedimento de uniformização de jurisprudência de competência do Tribunal da Relação, tribunal superior do Estado, cuja finalidade era a de eliminar eventual divergência jurisprudencial acerca da interpretação de norma jurídica aplicada nos processos de competência da justiça estadual. Nos termos do seu artigo 22:

Quando ocorrer manifesta contradicção entre decisões definitivas, no Tribunal da Relação, sobre questões de direito, o presidente, ex-officio, ou a requerimento do Procurador Geral, no interesse da lei e da uniformidade da jurisprudência, sujeitará, de novo a espécie ao tribunal e communicará a decisão ao governo, em relatório ciscumstanciado (sic), para ser presente ao poder legislativo. ${ }^{27}$

A Lei 17/1891 estruturou um procedimento de caráter repressivo, cabível após a constatação da existência de uma divergência interpretativa entre decisões judiciais proferidas pelo Tribunal da Relação. Lopes da Costa considerou o referido procedimento como uma providência para assegurar a uniformidade da jurisprudência e levar o Poder Legislativo a corrigir a obscuridade da lei28. Não era o procedimento aplicável na hipótese de divergência entre decisões de instâncias distintas, bem como não considerava, para fins de identificação de divergência, a interpretação realizada por órgãos da justiça federal,

\footnotetext{
${ }^{26}$ FRANCO, Virgílio Martins de Mello. A jurisprudência na organização do Direito Civil pátrio. Revista da Faculdade Livre de Direito do Estado de Minas Gerais, Ouro Preto, ano 1, n. 1, p. 93-100, 1894. Disponível em: https://www.direito.ufmg.br/revista/index.php/revista/article/view/438/407. Acesso em: 20 dez. 2017.

${ }^{27}$ MINAS GERAIS. Lei $\mathrm{n}^{\circ} 17$, de 20 de novembro de 1891. Estabelece o processo das causas cíveis e comerciais. In: Collecção das Leis Confeccionadas pelo Congresso em sua Primeira Reunião em 1891. Ouro Preto: Imprensa Oficial, 1895. Disponível em: https://dspace.almg.gov.br/handle/11037/4698. Acesso em: 30 dez. 2017.

${ }^{28}$ COSTA, Alfredo de Araújo Lopes da. Direito Processual Civil Brasileiro (Código de 1939). Rio de Janeiro: José Konfino Editor, 1948.
} 
sobretudo em função dos limites da competência legislativa conferida aos Estados pela Constituição de 1891.

O Código de Processo Civil mineiro, estabelecido pela Lei 830, de 1922, não estabeleceu procedimento voltado para a solução de conflito interpretativo ou capaz de assegurar a uniformidade das decisões judiciais. O Código de Processo Civil do Estado de São Paulo estabeleceu um procedimento interno para a uniformização da jurisprudência do seu tribunal. Trata-se da "revista", procedimento de natureza recursal, cabível contra decisão definitiva ou interlocutória de caráter definitivo proferida por uma das câmaras do tribunal e considerada divergente em face da jurisprudência deste, previsto nos artigos 1.119 a 1.126.

A revista, que tinha por objeto tão somente matéria de direito, poderia ser requerida pela parte vencida e seu julgamento procedente importava na cassação da decisão divergente e na prolação de nova decisão de acordo com a "interpretação vencedora” (art. 1123). Tal procedimento, no entanto, aplicava-se exclusivamente a hipótese de divergência entre os órgãos internos do Tribunal do Estado $^{29}$.

Procedimento semelhante de uniformização da jurisprudência dos tribunais foi previsto no Código de Processo do Distrito Federal. O Recurso de Revista era cabível na hipótese de nulidade manifesta ou ainda injustiça grave. Sua reincorporação ao Direito brasileiro após a proclamação da República, deu-se com a edição do Decreto ${ }^{\circ}$. 16.273, de 23 de dezembro de 1923, que organizou a estrutura judiciária do Distrito Federal.30 Nos termos desse decreto,

\footnotetext{
O recurso de revista seria admitido nos casos de violação ou falsa aplicação da lei; omissão de termos essenciais, exigidos por lei, sob pena de nulidade, que não tivesse sido sanada; divergência manifesta na interpretação da lei, entre Acórdãos de Câmaras diversas, mas de idêntica competencia ratione materiae..$^{31}$ (grifo nosso).
}

O recurso era cabível contra decisões definitivas passadas em julgado, proferidas em segunda instância. As hipóteses de cabimento do recurso foram previstas no inciso III do artigo 108 do referido decreto:

Art. 108. À Côrte de Appellação compete julgar em unica e definitiva instancia: $[\ldots]$

${ }^{29}$ SÃO PAULO. Lei n ${ }^{\circ} 2.421$, de 14 de janeiro de 1930. Código do Processo Civil e Commercial. São Paulo: Assembleia Legislativa do Estado de São Paulo, 1930. Disponível em: https://www.al.sp.gov.br/repositorio/legislacao/lei/1930/lei-2421-14.01.1930.html. Acesso em: 20 dez. 2017.

${ }^{30}$ COELHO, Vicente de Faria. Recurso de Revista. Rio de Janeiro: Editora Nacional de Direito Ltda, 1957.

${ }^{31}$ COELHO, Vicente de Faria. Recurso de Revista. Rio de Janeiro: Editora Nacional de Direito Ltda, 1957. 
III Os recursos de revista das sentenças definitivas, passadas em julgado, proferidas em gráo de appellação, não submettidas, antes, a seu julgamento, por meio de embargos e tão sómente nos casos seguintes:

a) de evidente violação ou falsa applicação da lei;

b) de omissão dos termos ou fórmas essenciaes prescriptos sob pena de nullidade, que não haja sido sanada;

c) de divergencia, implicando manifesta contradicção na interpretação da lei, entre julgados de Camaras diversas, com identica jurisdicção ratione materiae, desde que ellas não tenham procedido á fixação das normas de uniformização (art. $103) ;^{32}$

O recurso, cabível contra decisão transitada em julgado, ensejava a anulação da decisão recorrida. Ao mesmo não se atribuía eficácia suspensiva, permitindo a execução da decisão recorrida durante o seu processamento e tinha por objeto apenas matéria de direito. Neste sentido, estabelecia do artigo 111 do Decreto 16.173/1923: "É expressamente vedado à Côrte de Apelação, no caso de revista, entrar, sob qualquer pretexto na matéria de fato, devendo ser mantida sobre esta preferência pela sentença sujeita àquele recurso."

O recurso de revista foi mantido com a edição do novo Código de Processo Civil do Distrito Federal, estabelecido pelo Decreto 16.752, de 31 de dezembro de 1924, abolido pelo Decreto 5.053, de 06 de novembro de 1926 e novamente restabelecido pelo Decreto 21.228, de 31 de março de 1932. Por fim, após a Constituição de 1934, que atribuiu à União competência legislativa privativa para legislar sobre matéria processual, foi editada a Lei Federal no. 319, de 25 de novembro de 1936, que o regulamentou estabelecendo seu procedimento, estendendo sua aplicação a todos os tribunais.

O recurso de revista previsto no Decreto 16.273 de 1.923 do Distrito Federal serviu de inspiração para o legislador, quando da concentração da competência legislativa em matéria processual no âmbito da União e da publicação do primeiro código processual civil após a proclamação da república, o Código de Processo Civil de 1939.

A previsão do recurso de revista na legislação estadual, quando existente, entretanto, não foi suficiente para suprir a ausência de um instrumento de harmonização da interpretação do Direito, sobretudo se considerado o denunciado por Virgílio Martins de Mello Franco: a

\footnotetext{
${ }^{32}$ BRASIL. Decreto ${ }^{\circ}$ 16.273, de 23 de dezembro de 1923. Reorganiza a Justiça do Districto Federal. Rio de Janeiro: Presidência da República, 1923. Disponível em: https://www2.camara.leg.br/legin/fed/decret/19201929/decreto-16273-20-dezembro-1923-509027-publicacaooriginal-1-pe.html. Acesso em: 21 dez. 2017.
} 
duplicidade judiciária aliada à existência de uma legislação federal aplicável tanto por órgãos judiciários estaduais, quanto federais como fator de desestabilização da jurisprudência ${ }^{33}$

\section{Os procedimentos de uniformização no CPC de 1939: o recurso de revista e o prejulgado}

Com a promulgação da Constituição dos Estados Unidos do Brasil em 16 de julho de 1934, a competência legislativa em matéria processual foi atribuída privativamente à União, o que significa dizer que os Estados não possuíam mais a competência para legislar sobre a referida matéria.34 A concentração da competência legislativa em matéria processual no âmbito da União foi mantida com a Constituição brasileira de $1937^{335}$

Desta forma, coube à União legislar com exclusividade sobre matéria processual, e a substituição das legislações estaduais por uma legislação federal deu-se com a publicação do Código de Processo Civil, Decreto Lei no. 1.608, de 18 de setembro de 1939.

Segundo Lopes da Costa, o então novo Código de Processo Civil estabeleceu dois procedimentos recursais de garantia da uniformidade da interpretação do Direito, o recurso de revista e o recurso extraordinário, além de um procedimento autônomo, o prejulgado. $\mathrm{O}$ recurso de revista "se destina a manter a uniformidade da jurisprudência dentro da circunscrição judiciária do Estado. A uniformidade da jurisprudência entre os vários Estados da federação é mantida pelo recurso extraordinário". ${ }^{36}$

A previsão destes recursos apresentou-se como uma "necessidade de ordem prática", segundo Pedro Batista Martins, pois, “onde está a interpretação, está a divergência. Desde que se faculta a divisão de um mesmo tribunal em Câmaras ou Turmas, podem elas divergir na interpretação da mesma lei, assim como divergem os vários Tribunais locais". ${ }^{37}$

\footnotetext{
${ }^{33}$ FRANCO, Virgílio Martins de Mello. A jurisprudência na organização do Direito Civil pátrio. Revista da Faculdade Livre de Direito do Estado de Minas Gerais, Ouro Preto, ano 1, n. 1, p. 93-100, 1894. Disponível em: https://www.direito.ufmg.br/revista/index.php/revista/article/view/438/407. Acesso em: 20 dez. 2017.

${ }^{34}$ Neste sentido, ver o artigo 5", inciso XIX, "a" da Constituição da República dos Estados Unidos do Brasil, de 16 de julho de 1934 .

${ }^{35}$ Artigo 15, inciso XVI da Constituição dos Estados Unidos do Brasil, de 10 de novembro de 1937.

${ }^{36}$ COSTA, Alfredo de Araújo Lopes da. Direito Processual Civil Brasileiro (Código de 1939). Rio de Janeiro: José Konfino Editor, 1948.

${ }^{37}$ MARTINS, Pedro Batista. Recursos e processos da competência originária dos tribunais. Atualizado por Alfredo Buzaid. Rio de Janeiro: Revista Forense, 1957.
} 
Desta forma, dois os procedimentos de uniformização da jurisprudência regulados pelo Código de Processo Civil de 1939, o recurso de revista e o prejulgado.

Não obstante o nome "revista" ter sido utilizado anteriormente para a designação de procedimentos, como nas Ordenações Filipinas, em seu Livro 3o, Título XCV, com a expressão "Da revista dos Feitos", bem como na Constituição Imperial de 1824, artigo 164, inciso I, o recurso de revista previsto no Código de Processo Civil de 1939 tinha objeto e fim distintos, aproximando-se do recurso previsto nas legislações estaduais acima analisadas, sobretudo a adotado pelo Estado de São Paulo e pelo Distrito Federal.

Na sistemática do Código de Processo Civil de 1939, o recurso de revista estava regulado no Livro VII, "Dos recursos", Título V, "Da revista”, artigos 853 a 860. Nos termos do art. 853, caput:

Conceder-se-á recurso de revista para as Câmaras Civis reunidas, nos casos em que divergirem, em suas decisões finais, duas ou mais Câmaras, ou turmas, entre si, quanto ao modo de interpretar o direito em tese. Nos mesmos casos, será o recurso extensivo à decisão final de qualquer das Câmaras ou turmas, que contrariar outro julgado, também final, das Câmaras reunidas. ${ }^{38}$

Seu objetivo era a solução de divergências jurisprudenciais entre órgãos internos de um mesmo tribunal acerca do direito objetivo - norma jurídica em abstrato ${ }^{39}$, e seu objeto extrapolava os limites subjetivos da mesma, residindo na promoção da estabilidade das jurisprudências de um Tribunal através da uniformização das decisões dos seus órgãos internos ${ }^{40}$.

Ressalta Lopes da Costa, não possuir o recurso de revista a finalidade de garantir direito das partes, mas o "direito em tese". "O ponto de vista", afirma o autor, "não é mais subjetivo, preso ao caso concreto, com a sua prova, mas objetivo, abstrato, sem atender à

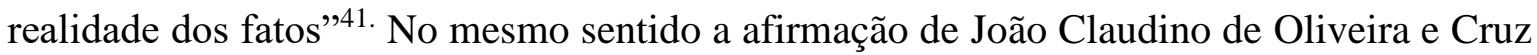
para quem o "recurso visa, assim, ao direito objetivo, e não ao direito subjetivo das partes". ${ }^{42}$

\footnotetext{
${ }^{38}$ BRASIL. Decreto-lei $\mathrm{n}^{\mathrm{o}}$ 1608, de 18 de setembro de 1939. Código de Processo Civil. Rio de Janeiro: Presidência da República, 1939. Disponível em: http://www.planalto.gov.br/ccivil_03/Decreto-Lei/19371946/Del1608.htm. Acesso em: 25 jan. 2018.

${ }^{39}$ COELHO, Vicente de Faria. Recurso de Revista. Rio de Janeiro: Editora Nacional de Direito Ltda, 1957.

${ }^{40}$ COSTA, Alfredo de Araújo Lopes da. Direito Processual Civil Brasileiro (Código de 1939). Rio de Janeiro: José Konfino Editor, 1948.

${ }^{41}$ COSTA, Alfredo de Araújo Lopes da. Direito Processual Civil Brasileiro (Código de 1939). Rio de Janeiro: José Konfino Editor, 1948.

${ }^{42}$ CRUZ, João Claudino de Oliveira e. Dos recursos no Código de Processo Civil. Rio de Janeiro: Revista Forense, 1954.
} 
O recurso de revista possuía pressupostos processuais específicos, dentre os quais destacavam-se: a) a necessidade do tribunal apresentar uma divisão orgânica interna em turmas ou câmaras; b) o necessário esgotamento das vias recursais ordinárias, uma vez que as decisões divergentes devem ser "finais"; e c) a existência de uma divergência e sua manifestação "na interpretação do direito em tese". ${ }^{43}$

Presentes os pressupostos processuais do recurso, o tribunal manifestava-se acerca da interpretação do direito em tese. O julgamento procedente do recurso de revista importava na fixação da interpretação a ser observada pelo órgão fracionário do tribunal autor da decisão recorrida, que deverá rever sua decisão, aplicando a nova interpretação fixada pelas Câmaras Civis reunidas ao caso concreto que originou a revista.

Divide-se o julgamento do recurso de revista em três etapas: a) a apuração da divergência; b) a interpretação que deve ser dada ao direito em teses, se a do acórdão recorrido, se a do apontado; c) a aplicação da tese vencedora ao caso em debate (acordão da 2a. Turma do STF, DE 2-5-47, Revista Forense, vol. CXIV, pág. 93). ${ }^{44}$

Desta forma, a decisão que julgava procedente o pedido formulado no recurso de revista produzia efeitos concretos, inter partes, não obstante conter uma interpretação "em tese" da norma objeto de divergência.

A exigência de pressupostos processuais específicos possibilitou caracterizar a revista como um recurso peculiar, excepcional, segundo Pedro Batista Martins. Sua função de uniformização do direito no âmbito dos tribunais complementava o recurso extraordinário como procedimento garantidor da uniformização da interpretação do direito em âmbito nacional.45

Entretanto, o recurso de revista foi objeto de inúmeras críticas, como anota Vicente de Faria Coelho. Uma delas, apresentada por Carvalho Santos, diz respeito à "possibilidade de constituir o referido recurso em um obstáculo ao desenvolvimento da jurisprudência", impossibilitando que a lei fosse "adaptada às necessidades sociais". A crítica, segundo Vicente Faria Coelho, não se sustentava, pois, "no seu julgamento os Tribunais adotarão a

\footnotetext{
${ }^{43}$ MARTINS, Pedro Batista. Recursos e processos da competência originária dos tribunais. Atualizado por Alfredo Buzaid. Rio de Janeiro: Revista Forense, 1957.

${ }^{44}$ CRUZ, João Claudino de Oliveira e. Dos recursos no Código de Processo Civil. Rio de Janeiro: Revista Forense, 1954.

${ }^{45}$ MARTINS, Pedro Batista. Recursos e processos da competência originária dos tribunais. Atualizado por Alfredo Buzaid. Rio de Janeiro: Revista Forense, 1957.
} 
interpretação dos ius in thesis, que mais condiga com as transformações aconselhadas pelas condições sociais, não será plausível por esse aspecto condená-lo". ${ }^{46}$

Pedro Batista Martins, na defesa do recurso de revista, afirmou que o mesmo não impedia que as turmas ou câmaras continuassem a divergir da decisão proferida pelas Câmaras reunidas, nem mesmo impossibilitava a revista evolução da jurisprudência, já que nova decisão em sede de recurso de revista poderia ser proferida, em razão dos novos argumentos trazidos pelos órgãos fracionários ${ }^{47}$.

Um segundo procedimento processual voltado para a uniformização da interpretação do direito e, por via de consequência, da jurisprudência dos tribunais, estabelecido pelo Código de Processo Civil de 1939 foi o prejulgado, regulado no artigo 861:

A requerimento de qualquer de seus juízes, a Câmara, ou turma julgadora, poderá promover o pronunciamento prévio da Câmaras reunidas sobre a interpretação de qualquer norma jurídica, se reconhecer que sobre ela ocorre ou poderá ocorrer, divergência de interpretação entre Câmaras ou Turmas $^{48}$

Neste sentido, aduziu o Professor José Olympio de Castro Filho que a "finalidade do instituto é de primeira intuição: vista, tal como o recurso de revista, à uniformização da jurisprudência do mesmo tribunal, com a característica de que procura a uniformização antes de se manifestar o dissídio jurisprudencial." ${ }^{49}$

O prejulgado configurava um procedimento preventivo de uniformização da jurisprudência, na medida em que pretendia oferecer uma interpretação uniforme acerca de norma jurídica cujo sentido fosse ou pudesse vir a ser objeto de divergência. O requisito do prejulgado residia, assim como o recurso de revista, na ausência de uma situação concreta de aplicação, pois a divergência era discutida em tese e não concretamente.

Possuindo ambos os procedimentos, revista e prejulgado, o mesmo objetivo, o de estabelecer uma interpretação única do direito em tese a ser observada pelos órgãos

\footnotetext{
${ }^{46}$ COELHO, Vicente de Faria. Recurso de Revista. Rio de Janeiro: Editora Nacional de Direito Ltda, 1957.

${ }^{47}$ MARTINS, Pedro Batista. Recursos e processos da competência originária dos tribunais. Atualizado por Alfredo Buzaid. Rio de Janeiro: Revista Forense, 1957.

${ }^{48}$ BRASIL. Decreto-lei no 1608, de 18 de setembro de 1939. Código de Processo Civil. Rio de Janeiro: Presidência da República, 1939. Disponível em: http://www.planalto.gov.br/ccivil_03/Decreto-Lei/19371946/Del1608.htm. Acesso em: 25 jan. 2018.

${ }^{49}$ CASTRO FILHO, José Olympio de. Prejulgado. Revista da Faculdade de Direito da UFMG, Belo Horizonte, v. $18, \quad$ p. 1984-1841, out. $1952 . \quad$ Disponível em: https://www.direito.ufmg.br/revista/index.php/revista/article/view/524/492: Acesso em 20 nov. 2017.
} 
fracionários de um mesmo tribunal, uma vez requerido o prejulgado, inviabilizava-se o manejo futuro da revista. ${ }^{50}$

Não obstante ter o Código de Processo Civil de 1939 incluído o prejulgado no mesmo título em que regulamentou o recurso de revista, ao mesmo não atribui a natureza de recurso. Como explica Pedro Batista Martins, "a falta de provocação do vencido e a falta de decisão contrária" descaracterizam o prejulgado como recurso, e sua inclusão entre os recursos justificar-se-ia em razão da afinidade que o mesmo guarda com o recurso de revista, qual seja, "a defesa da unidade do direito objetivo." 51

O pronunciamento das Câmaras reunidas podia ser requerido por qualquer juiz de turma ou câmara isolada do tribunal. Feito o requerimento, o órgão fracionário decidia acerca do encaminhamento da matéria ao plenário do tribunal, que se manifestava tão somente sobre a interpretação da norma objeto de dúvida. A interpretação fixada pelas Câmaras reunidas vinculava o órgão fracionário, ao qual competia a aplicação da norma com a interpretação conferida pelo órgão pleno e o julgamento do mérito do recurso. ${ }^{52}$

Verificada a divergência, desdobra-se a competência funcional: as Câmaras Reunidas julgarão a questão jurídica sobre a qual houverem divergido as câmaras singulares; a câmara singular a que estiver afeto o recurso decidirá todas as mais questões, de direito e de fato. ${ }^{53}$

Ressalte-se que a eficácia vinculante apenas era observada em relação ao processo no âmbito do qual a questão interpretativa foi suscita. A ausência de caráter vinculante talvez possa explicar o porquê foi o mesmo subutilizado.

No âmbito da Justiça do Trabalho, o prejulgado foi previsto como procedimento de competência do Tribunal Superior do Trabalho, estabelecendo o parágrafo primeiro do artigo 902 da CLT que os Tribunais Regionais do Trabalho, Juntas de Conciliação e Julgamento e Juízes ficavam vinculados às interpretações estabelecidas nos prejulgado. Diferentemente

\footnotetext{
${ }^{50}$ Em sentido contrário, entendem Lopes da Costa e José Olympio de Castro Filho, segundo os quais o recurso de revista poderá ser interposto contra a decisão da câmara singular, desde que tendo por fundamento questão jurídica diversa que suscite divergência interpretativa entre julgados. Neste sentido ver: CASTRO FILHO, José Olympio de. Prejulgado. Revista da Faculdade de Direito da UFMG. Out. 1952, p. 168; COSTA, 1948, p. 245. ${ }^{51}$ MARTINS, Pedro Batista. Recursos e processos da competência originária dos tribunais. Atualizado por Alfredo Buzaid. Rio de Janeiro: Revista Forense, 1957.

${ }^{52}$ MARTINS, Pedro Batista. Recursos e processos da competência originária dos tribunais. Atualizado por Alfredo Buzaid. Rio de Janeiro: Revista Forense, 1957.

${ }^{53}$ COSTA, Alfredo de Araújo Lopes da. Direito Processual Civil Brasileiro (Código de 1939). Rio de Janeiro: José Konfino Editor, 1948.
} 
do previsto no CPC de 1.939, a decisão do prejulgado celetista vinculava os órgãos do Judiciário Trabalhista verticalmente.

O prejulgado foi procedimento pouco utilizado, sendo sua ineficácia ressaltada por José Olympio de Castro Filho e Victor Nunes Leal, que denunciavam a sua "inoperância". A legitimidade para o seu requerimento restrito aos juízes, a conservadora organização dos tribunais em órgãos fracionários que atuam de forma isolada, o atraso na publicação dos boletins contendo a jurisprudência dos tribunais e, por fim, a falta de estudo adequado são os principais fatores que justificariam a ineficácia do prejulgado, segundo Castro Filho.54

\section{O recurso extraordinário como instrumento de uniformização da interpretação do Direito}

O recurso em matéria constitucional foi introduzido no Direito brasileiro com a Proclamação da República e subsequente substituição do Superior Tribunal de Justiça pelo Supremo Tribunal Federal. O Decreto 848, de 11 de outubro de 1890, que organizou a justiça federal, previu a possibilidade de recurso ao Supremo Tribunal Federal contra decisões proferidas pelos tribunais federais e estaduais, relativamente a matéria constitucional, previsão mantida pela Constituição de 1891. O recurso previsto no artigo 59, 3., §1o consubstanciava o principal instrumento de controle difuso de constitucionalidade das leis no âmbito do Supremo Tribunal Federal.

Com a promulgação da Constituição de 1934, o referido recurso foi mantido, com a denominação de recurso extraordinário. As hipóteses de cabimento, entretanto, foram alteradas, tendo sido incluída uma possibilidade de recurso baseada na existência de diversidade de interpretação da lei por parte dos tribunais federais ou estaduais. A divergência interpretativa não se restringia à matéria constitucional. Alterou-se também a denominação do tribunal, que passou a ser chamado de Corte Suprema. Nesse sentido, estabelecia a Constituição de 1934:

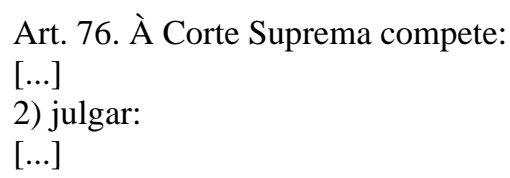

${ }^{54}$ CASTRO FILHO, José Olympio de. Prejulgado. Revista da Faculdade de Direito da UFMG, Belo Horizonte, v. $18, \quad$ p. $1984-1841, \quad$ out. $1952 . \quad$ Disponível em: https://www.direito.ufmg.br/revista/index.php/revista/article/view/524/492: Acesso em 20 nov. 2017. 
III - em recurso extraordinário, as causas decididas pelas Justiças locais em única ou última instância:

[...]

d) quando ocorrer diversidade de interpretação definitiva de lei federal entre Cortes de Apelação de Estados diferentes, inclusive do Distrito Federal ou dos Territórios, ou entre um destes tribunais e a Corte Suprema, ou ouro tribunal federal. ${ }^{55}$

A Constituição de 1937 manteve a hipótese semelhante no tocante à possibilidade de recurso extraordinário fundada na interpretação divergente entre tribunais, assim como as Constituições de 1946 (art. 101, inciso III, d), 1967 (art. 119, inciso III, d) e a Emenda Constitucional no. 1/69 (art. 119, inciso III, d).

Tais hipóteses de recurso não se fundavam na interpretação de dispositivos legais à luz da Constituição Federal, mas na possibilidade de se estabelecer uma interpretação da legislação nacional por parte do órgão de cúpula do Poder Judiciário brasileiro.

A decisão proferida em sede de recurso extraordinário não vinculava os demais órgãos do Poder Judiciário, não possuindo eficácia vinculante. Sua eficácia restringia-se aos limites subjetivos do processo no âmbito do qual a mesma foi proferida, ou seja, produzia eficácia inter partes.

\section{As súmulas e a uniformização do Direito no âmbito do Supremo Tribunal Federal}

A busca pela uniformidade na interpretação e aplicação no âmbito do Supremo Tribunal Federal levou à introdução das Súmulas, que surgiram sobretudo em função da necessidade de se conferir maior celeridade e organicidade à atuação do órgão de cúpula do Poder Judiciário.

Segundo o Victor Nunes Leal, ministro do Supremo Tribunal Federal responsável pela introdução da Súmula no âmbito deste tribunal, a mesma consistia em método de trabalho destinado a ordenar melhor e facilitar a tarefa judicante. ${ }^{56}$

${ }^{55}$ BRASIL. [Constituição (1934)]. Constituição da República dos Estados Unidos do Brasil, de 16 de julho de 1934. Disponível em http://www.planalto.gov.br/ccivil_03/constituicao/constituicao34.htm. Acesso em: 20 jan. 2018.

${ }^{56}$ LEAL, Victor Nunes. Passado e futuro da súmula do STF. Revista de Direito Administrativo, Rio de Janeiro, v. 145, p. 1-20, jan. 1981. Disponível em: http://bibliotecadigital.fgv.br/ojs/index.php/rda/article/view/43387. Acesso em: 24 jan. 2018. 
Súmula da jurisprudência Predominante do Supremo Tribunal Federal é o enunciado no qual o Tribunal inscreve o seu entendimento sobre as questões mais controvertidas na jurisprudência e sobre as quis o STF chegou a uma opinião firme, em face da sua composição contemporânea. É o pensamento dominante do Supremo em determinada época. Método de trabalho que visa simplificar os julgamentos no STF e divulgar a jurisprudência ${ }^{57}$

A necessidade de se conferir maior celeridade à atuação do Supremo Tribunal Federal foi um dos principais motivos que levou à introdução das Súmulas. Segundo Dias, dois eram os problemas apontados pelo Victor Nunes Leal e que contribuíam para a demora no julgamento dos processos no âmbito do STF: a ausência de divulgação adequada das decisões do próprio tribunal, o que contribuía para o seu desconhecimento, e o acúmulo de processos versando sobre matéria repetitiva.58

Com relação ao primeiro problema, Victor Nunes Leal buscou o aperfeiçoamento das publicações oficiais do Supremo Tribunal Federal, reduzindo o lapso temporal entre a data do julgamento e a sua publicação. Já em relação ao segundo problema, propôs a introdução das Súmulas.

A Súmula nasce para expressar a orientação dominante do Tribunal acerca de tema controvertido na jurisprudência e eliminar divergências anteriores. Cumpre com eficiência os dois objetivos almejados: divulgar a jurisprudência e acelerar os julgamentos. ${ }^{59}$

A Súmula apresentava-se como um instrumento flexível, posto que uma vez adotada, podia ser alterada, bem como cancelada, e refletia "uma posição equilibrada, isto é, sem qualquer excesso." Ainda nas palavras de Victor Nunes Leal, a Súmula configurava um meio termo entre os assentos da Casa da Suplicação, que proviam uma interpretação definitiva do Direito, e a ineficácia do prejulgado. ${ }^{60}$

Assim, introduzida em 1963, através de Emenda ao Regimento Interno do Supremo Tribunal Federal, publicada em 30.08.63 no Diário da Justiça, a Súmula passou a vigorar a partir do ano judiciário de 1964. No mês de dezembro de 1963 foram editadas as primeiras

${ }^{57}$ DIAS, Marcus Gil Barbosa. A evolução histórica das súmulas no Supremo Tribunal Federal. São Paulo: Schoba, 2009.

${ }^{58}$ DIAS, Marcus Gil Barbosa. A evolução histórica das súmulas no Supremo Tribunal Federal. São Paulo: Schoba, 2009.

${ }^{59}$ DIAS, Marcus Gil Barbosa. A evolução histórica das súmulas no Supremo Tribunal Federal. São Paulo: Schoba, 2009.

${ }^{60}$ LEAL, Victor Nunes. Passado e futuro da súmula do STF. Revista de Direito Administrativo, Rio de Janeiro, v. 145, p. 1-20, jan. 1981. Disponível em: http://bibliotecadigital.fgv.br/ojs/index.php/rda/article/view/43387. Acesso em: 24 jan. 2018. 
Súmulas, um total de 370. A competência para sua edição foi atribuída ao plenário do Supremo Tribunal Federal, que também detinha poderes para alterá-la e cancelá-la, nos termos do arts. 7o e 8o. da referida Emenda ${ }^{61}$

Com a Constituição Federal de 1967, foi atribuída ao Supremo Tribunal Federal poderes para estabelecer, através do seu regimento interno, normas sobre o processo e julgamento dos feitos de sua competência, originária ou recursal. Tem-se, desta forma, a constitucionalização das súmulas, pondo-se fim às discussões acerca da sua validade. ${ }^{62}$

Posteriormente foram realizadas novas alterações do Regimento Interno do Supremo Tribunal de modo a aperfeiçoar o processo de edição de súmulas. Assim, o RISTF dispunha sobre o processo de inclusão, alteração ou cancelamento das súmulas pelo STF. Em linhas gerais, estabelecia o Regimento, no artigo 102 e seguinte a competência do plenário, o quórum da maioria absoluta para sua aprovação, modificação ou cancelamento, o sistema de numeração sucessivo, a publicação das súmulas, estabelecendo, por fim que, a citação Súmula dispensava o órgão do PJ de fazer referência a outros julgados no mesmo sentido.

Segundo o Ministro Victor Nunes Leal a partir da adoção da Súmula de jurisprudência dominante pelo STF, outros órgãos do Poder Judiciário passaram a adotar idêntico método de trabalho, como, por exemplo, o Tribunal Federal de Recursos, pelo Tribunal Superior do Trabalho e nos Tribunais de Alçada de São Paulo. ${ }^{63}$

José Pereira Lira afirmou ser aquela "a hora e vez da jurisprudência", que se transformava em fonte do Direito. Com a edição das súmulas, a jurisprudência ganhava racionalidade, alcançando status científico. ${ }^{64}$

No âmbito dos tribunais, a edição das súmulas foi possível graças à previsão do incidente de uniformização de jurisprudência previsto no Código de Processo Civil de 1973, nos artigos 476 a 479. As súmulas figuraram como o resultado da uniformização da

${ }^{61}$ BRASIL. Supremo Tribunal Federal. Emendas do Regimento. Diário da Justiça. Ano XXXVIII - No. 164. Brasília. $\quad 30 \quad$ de agosto $\quad$ de $1963 . \quad$ Disponível em: http://www.stf.jus.br/arquivo/cms/bibliotecaConsultaProdutoBibliotecaRI/anexo/1940/art_183_3agosto1963. pdf. Acesso em: 25 jan. 2018.

${ }^{62}$ LEAL, Victor Nunes. Passado e futuro da súmula do STF. Revista de Direito Administrativo, Rio de Janeiro, v. 145, p. 1-20, jan. 1981. Disponível em: http://bibliotecadigital.fgv.br/ojs/index.php/rda/article/view/43387. Acesso em: 24 jan. 2018.

${ }^{63}$ LEAL, Victor Nunes. Passado e futuro da súmula do STF. Revista de Direito Administrativo, Rio de Janeiro, v. 145, p. 1-20, jan. 1981. Disponível em: http://bibliotecadigital.fgv.br/ojs/index.php/rda/article/view/43387. Acesso em: 24 jan. 2018.

${ }^{64}$ LIRA, José Pereira. O direito sumular. Revista do Serviço Público, Brasília-Distrito Federal, no . 2, p. 79-90, 1971. Disponível em: https://revista.enap.gov.br/index.php/RSP/article/view/2498. Acesso em: 15. dez. 2017. 
jurisprudência no âmbito dos tribunais, procedimento esse que substituiu o prejulgado previsto no Código de Processo Civil de 1939. Nesse sentido, o artigo 479 do CPC de 1973 estabeleceu que "o julgamento, tomado pelo voto da maioria absoluta dos membros que integram o tribunal, será objeto de súmula e constituirá precedente na uniformização da jurisprudência." ${ }^{65}$ (grifo acrescido)

Um aspecto interessante acerca da aplicação da súmula, enquanto instrumento de uniformização da interpretação do Direito, diz respeito à possibilidade de interpretação do seu enunciado. Isto porque, como afirmou Nunes Leal, a mesma consubstancia o resultado do processo de interpretação. Interpretar a súmula importaria uma redundância, uma interpretação de uma interpretação.

Cuidando ainda da Súmula como método de trabalho - aspecto em relação ao qual seria até indiferente o conteúdo dos seus enunciados - é oportuno mencionar que estes não devem ser interpretados, isto é, esclarecidos quanto ao seu correto significado. O que se interpreta é a norma da lei ou do regulamento, e a Súmula é o resultado dessa interpretação, realizada pelo Supremo Tribunal Federal ${ }^{66}$

A eficácia da súmula restringia-se à atuação do próprio Supremo Tribunal Federal, não vinculando os demais órgãos do Poder Judiciário. Entretanto, a possibilidade de reforma das decisões judiciais objeto de recurso junto ao STF, com base na aplicação da súmula, acabava por promover a sua observância por parte dos demais órgãos do Poder Judiciário brasileiro.

\section{Conclusão}

A reconstrução dos procedimentos de uniformização da intepretação possibilita a identificação de características comuns aos mesmos, dentre as quais destaca-se a preocupação do legislador em assegurar uma uniformidade de interpretação a partir da fixação de uma interpretação do direito objetivo, uma interpretação abstrata. A interpretação

65 BRASIL. Lei $\mathrm{n}^{\circ}$ 5.869, de 11 de janeiro de 1973. Institui o Código de Processo Civil. Brasília, DF: Presidência da República, 1937. Disponível em: http://www2.camara.leg.br/legin/fed/lei/1970-1979/lei-586911-janeiro-1973-357991-publicacaooriginal-1-pl.html. Acesso em: 25 jan. 2018.

${ }^{66}$ LEAL, Victor Nunes. Passado e futuro da súmula do STF. Revista de Direito Administrativo, Rio de Janeiro, v. 145, p. 1-20, jan. 1981. Disponível em: http://bibliotecadigital.fgv.br/ojs/index.php/rda/article/view/43387. Acesso em: 24 jan. 2018. 
contida nos assentos possuía caráter abstrato, referindo-se à norma objeto de aplicação, sem conexão com a situação fática concreta objeto de análise pelo órgão judiciário.

O recurso de revista, previsto no Código de Processo Civil de 1939, em seu artigo 853, também fornecia uma interpretação em tese do direito cujo sentido era objeto de divergência entre os órgãos internos de um mesmo tribunal, assim como o prejulgado possibilitava ao tribunal fixar uma interpretação do direito objetivo, desvinculado de um caso concreto. Em todos esses procedimentos, a preocupação com a uniformidade decisória resultou na adoção de procedimentos no âmbito dos quais o caso concreto não constituía elemento relevante.

Outro aspecto comum aos procedimentos de uniformização diz respeito aos limites subjetivos do provimento que continha a interpretação uniforme. Com exceção dos assentos que continham a "inteligência geral" do Direito, as decisões decorrentes do julgamento do recurso de revista, do prejulgado e do recurso extraordinário aplicavam-se apenas em relação ao processo no qual foi a dúvida relativa à interpretação suscitada e exclusivamente no âmbito do tribunal.

Nenhum dos procedimentos analisados, à exceção dos assentos da Casa de Suplicação, consistiam em procedimentos de interpretação do Direito observável por todos os órgãos do Poder Judiciário.

Da perspectiva constitucional, pode-se verificar uma omissão no que tange à organização judiciária nacional, relativamente à existência de um órgão judiciário intérprete da legislação federal, papel hoje desempenhado pelos Tribunais Superiores. Por outro lado, se faz perceptível a ausência de procedimentos capazes de assegurar a uniformidade que leve em consideração aspectos concretos relevantes e que devem ser sopesados no processo interpretativo do Direito. Ainda que se busque uma interpretação objetiva, abstrata, o sentido da norma a aplicar somente é reconstruído em face da situação concreta de aplicação.

A reconstrução dos procedimentos voltados à uniformização da intepretação permite concluir que a busca por uma interpretação coerente do Direito não configura uma preocupação exclusiva do legislador atual, mas se perfaz como uma constante na história do Direito Processual brasileiro.

\section{REFERÊNCIAS}


ALMEIDA JUNIOR, João Mendes de. Direito Judiciário brasileiro. 5. ed. Rio de Janeiro: Freitas Bastos, 1960.

BRASIL. [Constituição (1934)]. Constituição da República dos Estados Unidos do Brasil, de 16 de julho de 1934. Disponível em http://www.planalto.gov.br/ccivil_03/constituicao/constituicao34.htm. Acesso em: 20 jan. 2018.

BRASIL. [Constituição (1891)]. Constituição dos Estados Unidos do Brasil, de 24 de $\begin{array}{lllll}\text { fevereiro } & \text { de } & 1891 . & \text { Disponível }\end{array}$ http://www.planalto.gov.br/ccivil_03/Constituicao/Constituicao91.htm. Acesso em: 01 ago. 2016.

BRASIL. Decreto-lei n ${ }^{\circ}$ 1608, de 18 de setembro de 1939. Código de Processo Civil. Rio de Janeiro: Presidência da República, 1939. Disponível em: http://www.planalto.gov.br/ccivil_03/Decreto-Lei/1937-1946/Del1608.htm. Acesso em: 25 jan. 2018.

BRASIL. Decreto $n^{\circ} 2.684$, de 23 de outubro de 1875. Dá força de lei no Imperio a assentos da Casa da Supplicação de Lisboa e competencia ao Supremo Tribunal de Justiça para tomar outros. Disponível em: https://www2.camara.leg.br/legin/fed/decret/18241899/decreto-2684-23-outubro-1875-549772-publicacaooriginal-65290-pl.html. Acesso em: 25 jan. 2018.

BRASIL. Decreto ${ }^{\circ} 16.273$, de 23 de dezembro de 1923. Reorganiza a Justiça do Districto Federal. Rio de Janeiro: Presidência da República, 1923. Disponível em: https://www2.camara.leg.br/legin/fed/decret/1920-1929/decreto-16273-20dezembro-1923-509027-publicacaooriginal-1-pe.html. Acesso em: 21 dez. 2017.

BRASIL. Lei $n^{\circ}$ 5.869, de 11 de janeiro de 1973. Institui o Código de Processo Civil. Brasília, DF: Presidência da República, 1937. Disponível em: http://www2.camara.leg.br/legin/fed/lei/1970-1979/lei-5869-11-janeiro-1973357991-publicacaooriginal-1-pl.html. Acesso em: 25 jan. 2018.

BRASIL. Supremo Tribunal Federal. Emendas do Regimento. Diário da Justiça. Ano XXXVIII - No. 164. Brasília. 30 de agosto de 1963. Disponível em: http://www.stf.jus.br/arquivo/cms/bibliotecaConsultaProdutoBibliotecaRI/anexo/194 0/art_183_3agosto1963.pdf. Acesso em: 25 jan. 2018. 
CARMIGNANI, Maria Cristina da Silva. O direito judiciário lusitano - os assentos da casa da suplicação. Revista da Faculdade de Direito, Universidade de São Paulo, São Paulo, v. 111, p. 19-29, jun. 2017. Disponível em: <https://www.revistas.usp.br/rfdusp/article/view/133541/129548>. Acesso em: 16 jan. 2018.

CASTRO FILHO, José Olympio de. Prejulgado. Revista da Faculdade de Direito da UFMG, Belo Horizonte, v. 18, p. 1984-1841, Out. 1952. Disponível em: https://www.direito.ufmg.br/revista/index.php/revista/article/view/524/492: Acesso em 20 nov. 2017.

COELHO, Vicente de Faria. Recurso de Revista. Rio de Janeiro: Editora Nacional de Direito Ltda, 1957.

COSTA, Alfredo de Araújo Lopes da. Direito Processual Civil Brasileiro (Código de 1939). Rio de Janeiro: José Konfino Editor, 1948.

CRUZ, João Claudino de Oliveira e. Dos recursos no Código de Processo Civil. Rio de Janeiro: Revista Forense, 1954.

CRUZ E TUCCI, José Rogério. Tradição luso-brasileira dos assentos da Casa da Suplicação. São Paulo: Atlas, 2012.

DIAS, Marcus Gil Barbosa. A evolução histórica das súmulas no Supremo Tribunal Federal. São Paulo: Schoba, 2009.

FRANCO, Virgílio Martins de Mello. A jurisprudência na organização do Direito Civil pátrio. Revista da Faculdade Livre de Direito do Estado de Minas Gerais, Ouro Preto, ano 1, n. 1, p. 93-100, 1894. Disponível em: https://www.direito.ufmg.br/revista/index.php/revista/article/view/438/407. Acesso em 20 de dezembro de 2017.

LAGES, Cintia Garabini; CHAMON JUNIOR, Lúcio Antônio. Acerca da segurança jurídica e da uniformidade das decisões a partir do novo código de processo civil à luz do modelo constitucional do processo brasileiro. Rev. Bras. Polít. Públicas, Brasília, v. 7, $\mathrm{n}^{\circ} 2$, p. 285-301, ago. 2017.

LEAL, Victor Nunes. Passado e futuro da súmula do STF. Revista de Direito Administrativo, Rio de Janeiro, v. 145, p. 1-20, jan. 1981. Disponível em: 
http://bibliotecadigital.fgv.br/ojs/index.php/rda/article/view/43387. Acesso em: 24 jan. 2018.

LIRA, José Pereira. O direito sumular. Revista do Serviço Público, Brasília-Distrito Federal, no. 2, p. 79-90, $1971 . \quad$ Disponível em: https://revista.enap.gov.br/index.php/RSP/article/view/2498. Acesso em: 15. dez. 2017.

MARTINS, Pedro Batista. Recursos e processos da competência originária dos tribunais. Atualizado por Alfredo Buzaid. Rio de Janeiro: Revista Forense, 1957.

MINAS GERAIS. Constituição Política do Estado de Minas Gerais, de 15 de junho de 1891. Disponível em: https://www.almg.gov.br/consulte/legislacao/completa/completa.html?tipo=CON\&n $\underline{u m=1891 \& \text { comp }=\& a n o=1891}$. Acesso em: $30 \mathrm{dez} .2017$.

MINAS GERAIS. Lei no 17, de 20 de novembro de 1891. Estabelece o processo das causas cíveis e comerciais. In: Collecção das Leis Confeccionadas pelo Congresso em sua Primeira Reunião em 1891. Ouro Preto: Imprensa Oficial, 1895. Disponível em: https://dspace.almg.gov.br/handle/11037/4698. Acesso em: 30 dez. 2017.

NOGUEIRA, Octaciano. Constituições Brasileiras: 1824. Brasília: Senado Federal e Ministério da Ciência e Tecnologia, Centro de Estudos Estratégicos, 2001.

RIBEIRO, Teóphilo. As Ordenações do Reino. Revista da Faculdade de Direito da UFMG, Belo Horizonte, v. 5, p. 155-208, abr. 2014. Disponível em: 〈https://www.direito.ufmg.br/revista/index.php/revista/article/view/1367/1299>. Acesso em: 10 dez. 2017.

SÃO PAULO. Lei no 2.421, de 14 de janeiro de 1930. Código do Processo Civil e Commercial. São Paulo: Assembleia Legislativa do Estado de São Paulo, 1930. Disponível em: https://www.al.sp.gov.br/repositorio/legislacao/lei/1930/lei-242114.01.1930.html. Acesso em: 20 dez. 2017.

TELLES, José Homem Correa. Commentário crítico à Lei da Boa Razão em data de 18 de agosto de 1769. Lisboa: Typographia de Maria Madre de Deus, 1.865.

VIANA, Juvêncio Vasconcelos. História do processo: uma análise do Código de Processo Civil de 1939 sob o prisma terminológico. Revista da Procuradoria Geral do Município de Fortaleza, Fortaleza, v. 9, p. 129-162, 2001. Disponível em: 
Revista Eletrônica de Direito Processual - REDP.

Rio de Janeiro. Ano 15. Volume 22. Número 3. Setembro a Dezembro de 2021

Periódico Quadrimestral da Pós-Graduação Stricto Sensu em Direito Processual da UERJ

Patrono: José Carlos Barbosa Moreira (in mem.). ISSN 1982-7636. pp. 192-219

www.redp.uerj.br

https://revista.pgm.fortaleza.ce.gov.br/revista1/issue/view/9/ano2001. Acesso em: 02

nov. 2017. 